\title{
How many bird extinctions have we prevented?
}

\author{
Stuart H.M. Butchart, Alison J. Stattersfield and Nigel J. Collar
}

\begin{abstract}
Considerable resources and efforts have been directed at biodiversity conservation in recent years, but measures of the success of conservation programmes have been limited. Based on information on population sizes, trends, threatening processes and the nature and intensity of conservation actions implemented during 1994-2004, we assessed that 16 bird species would have probably become extinct during this period if conservation programmes for them had not been undertaken. The mean minimum population size of these 16 species increased from 34 to 147 breeding individuals during 1994-2004. In 1994, 63\% of them had declining populations but by 2004, $81 \%$ were increasing. Most of these species (63\%) are found on islands. The principal threats that led to their decline were habitat loss and degradation $(88 \%)$, invasive species $(50 \%)$ and exploitation $(38 \%)$, a pattern similar to that for other threatened species, but with exploitation and invasive species being relatively more
\end{abstract}

important. The principal actions carried out were habitat protection and management (75\% of species), control of invasive species $(50 \%)$, and captive breeding and release (33\%). The 16 species represent only $8.9 \%$ of those currently classified as Critically Endangered, and 1.3\% of those threatened with extinction. Many of these additional species slipped closer to extinction during 1994-2004, including 164 that deteriorated in status sufficiently to be uplisted to higher categories of extinction risk on the IUCN Red List (IUCN, 2006). Efforts need to be considerably scaled up to prevent many more extinctions in the coming decades. The knowledge and tools to achieve this are available, but we need to mobilize the resources and political will to apply them.

Keywords Conservation action, Critically Endangered, exploitation, extinction, invasive species, IUCN Red List.

\section{Introduction}

The world's biodiversity is being destroyed at everincreasing rates (Jenkins et al., 2003), and recent extinction rates are 1,000-11,000 higher than background rates (Pimm \& Brooks, 1999). This situation has prompted the nations of the world to pledge to reduce significantly the rate of biodiversity loss by 2010 (Secretariat of the Convention on Biological Diversity, 2003). Certainly, substantial resources have been spent on conserving biodiversity in recent years. For example, based on figures from the mid 1990s, James et al. (2001) estimated that USD 6 billion is spent annually on management of protected areas alone. The US Fish and Wildlife Service's budget alone in 2004 was almost USD 1.3 billion in 2004 (USFWS, 2004a), while in 2003 the combined state and federal spending totalled USD 16 million for bald eagle Haliaeetus leucocephalus and USD 12.4 million for red-cockaded woodpecker Picoides borealis, and six other species received more than USD

Stuart H. M. Butchart (Corresponding author), Alison J. Stattersfield and Nigel J. Collar BirdLife International, Wellbrook Court, Girton Road, Cambridge, CB3 ONA, UK. E-mail stuart.butchart@birdlife.org

Received 18 November 2005. Revision requested 6 April 2006. Accepted 7 June 2006.
5 million each (Anon., 2005). In Australia, nearly USD 22 million was spent on the conservation of 78 threatened bird taxa during 1993-2000. This equated to USD 480,000 per Critically Endangered species and more than USD 5,500 per individual bird for these species over the same 8-year period (although it should be noted that conservation benefits often extend beyond the particular species targeted; Garnett et al., 2003).

Has this funding had any effect on extinction rates? Unfortunately, because extinctions are difficult to detect extinction rates are problematic to estimate (Diamond, 1987; Butchart et al., 2006). For a species to be listed as Extinct requires exhaustive surveys to have been undertaken in all known or likely habitat throughout its historic range, at appropriate times (diurnal, seasonal, annual) and over a time frame appropriate to its life cycle and life form (IUCN, 2001). Even among birds, the best known class of organisms, there are 16 species that are classified as Critically Endangered (Possibly Extinct) because their extinction is suspected but requires confirmation (Butchart et al., 2006). One of these probably went extinct in the wild during 1994-2004 (Spix's macaw Cyanopsitta spixii in 2001) and two other species are confirmed to have gone extinct during this period: nukupu'u Hemignathus lucidus disappeared in 1996 and Hawaiian crow Corvus hawaiiensis went extinct 
in the wild in 2002 (BirdLife International, 2004a; Butchart et al., 2006). Many other bird species slipped closer to extinction, showing reduced populations or increasing rates of decline, but not at a rate sufficient to cross thresholds for higher categories on the IUCN Red List.

One measure of whether conservation efforts have had any success in reducing these deteriorating trends is to determine if conservation programmes have managed to prevent any extinctions. In order to address this question we examined information on the population size and trends of the world's birds, the threats to them, and the conservation actions taken during the decade 1994-2004.

\section{Methods}

To identify those species for which conservation may have prevented extinction during 1994-2004 we drew up a list of candidates by examining information on all 168 species classified as Critically Endangered in 1994, plus 73 species that would have qualified had current information been available then. We identified 27 such candidate species that (a) are currently still recognized taxonomically as species, (b) had a known population during 1994-2004, (c) are believed on present knowledge to have still been extant in 1994 and remained extant in 2004, (d) had a minimum population estimated to be $<100$ individuals in 1994 or had a population that was estimated to be $<200$ individuals and estimated, inferred or suspected to be declining at a rate $>80 \%$ over 10 years or three generations (whichever was longer, as specified in the IUCN Red List criteria; IUCN, 2001), and (e) received direct conservation interventions during 1994-2004 that significantly mitigated a key threat to the species. We chose the period 1994-2004 because the best information is available for this period: Collar et al. (1994) provided the first assessment of all the world's birds for the IUCN Red List using the explicitly quantitative Mace-Lande extinction risk criteria, and gave sufficient information to make comparisons with the status of these species as assessed in BirdLife International (2004a).

We then examined each of the 27 candidate species in greater detail to assess the likelihood that they would have failed to survive if conservation action for them had ceased in 1994. Insufficient data were available to carry out detailed population modelling to quantify their extinction probability in the absence of conservation action. Instead, we attempted to decide as objectively as possible, considering the population size, trends, severity of threats and intensity and effectiveness of conservation interventions, whether each species was likely to have gone extinct had conservation action ceased in 1994. We gathered such information from the accounts published in Collar et al. (1994) and BirdLife International (2000, 2001, 2004b), and from personal communication with species experts (see Acknowledgements). For each species we weighed up this evidence and estimated the probability that they would have gone extinct during the period as certain, very high, high, medium or low.

To compare species that avoided extinction with other threatened species, we categorized their threats according to the classification of IUCN (IUCN, 2006). For species that avoided extinction, we identified the most important threats that led to their population declines, and also the most important threats addressed by conservation action that led to recoveries or reduced declines. We compared these to 'high' and 'medium' impact threats for other threatened species (calculated from scores for timing, scope and severity: see BirdLife International, $2004 \mathrm{~b}$, for details).

The possibility exists that so-called charismatic species attract more conservation attention than others, and we tested for this by separating out large, conspicuous and/or colourful species as charismatic (hence including albatrosses, waterbirds, raptors, galliformes, pigeons, parrots, hummingbirds, hornbills and some brightly or strikingly patterned or coloured passerines).

\section{Results}

Of 27 possible candidates, we judged that 16 species would probably have gone extinct in the absence of conservation intervention from 1994 to 2004, based on assessments of their population sizes and trends, the threats affecting them and the conservation actions undertaken. This total includes one species that became extinct in the wild briefly during the period (California condor Gymnogyps californianus), nine species that we estimate had a very high likelihood they would have gone extinct, and six species with a high likelihood (Table 1). The remaining 11 species were judged likely to have been close to extinction during this period, but were estimated to have a low (10 species) or medium (one species) likelihood that they would have gone extinct in the absence of conservation action (Table 2).

The 16 species that were prevented from going extinct all had very small population sizes at the beginning of the period. Their mean minimum population size in 1994 was 34 individuals (range 8-118 breeding individuals, where these data are available), with only four known breeding pairs of Chatham Island taiko Pterodroma magentae, four surviving female Norfolk Island green parrots Cyanoramphus cookii and the entire (previously released) population of California 


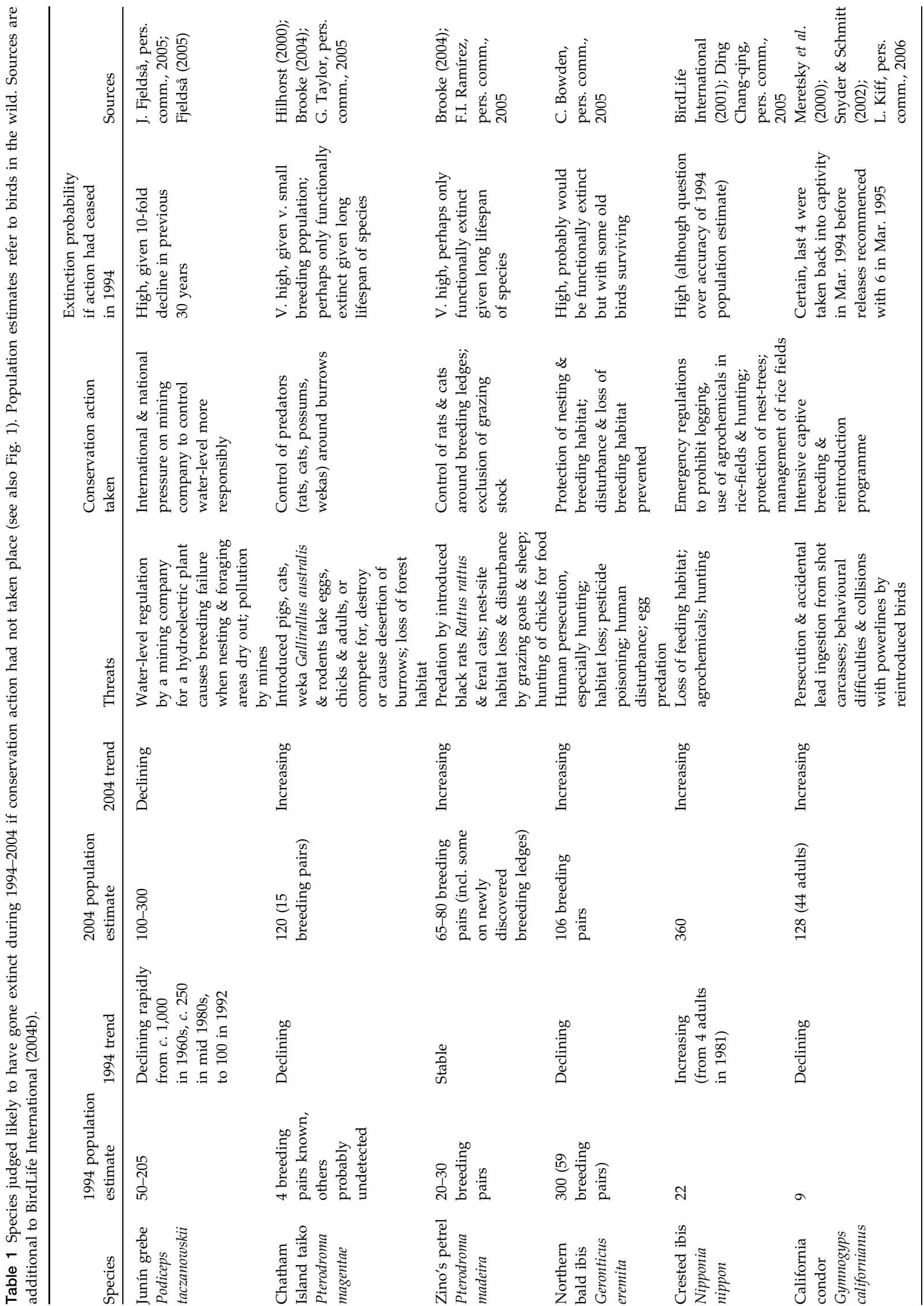




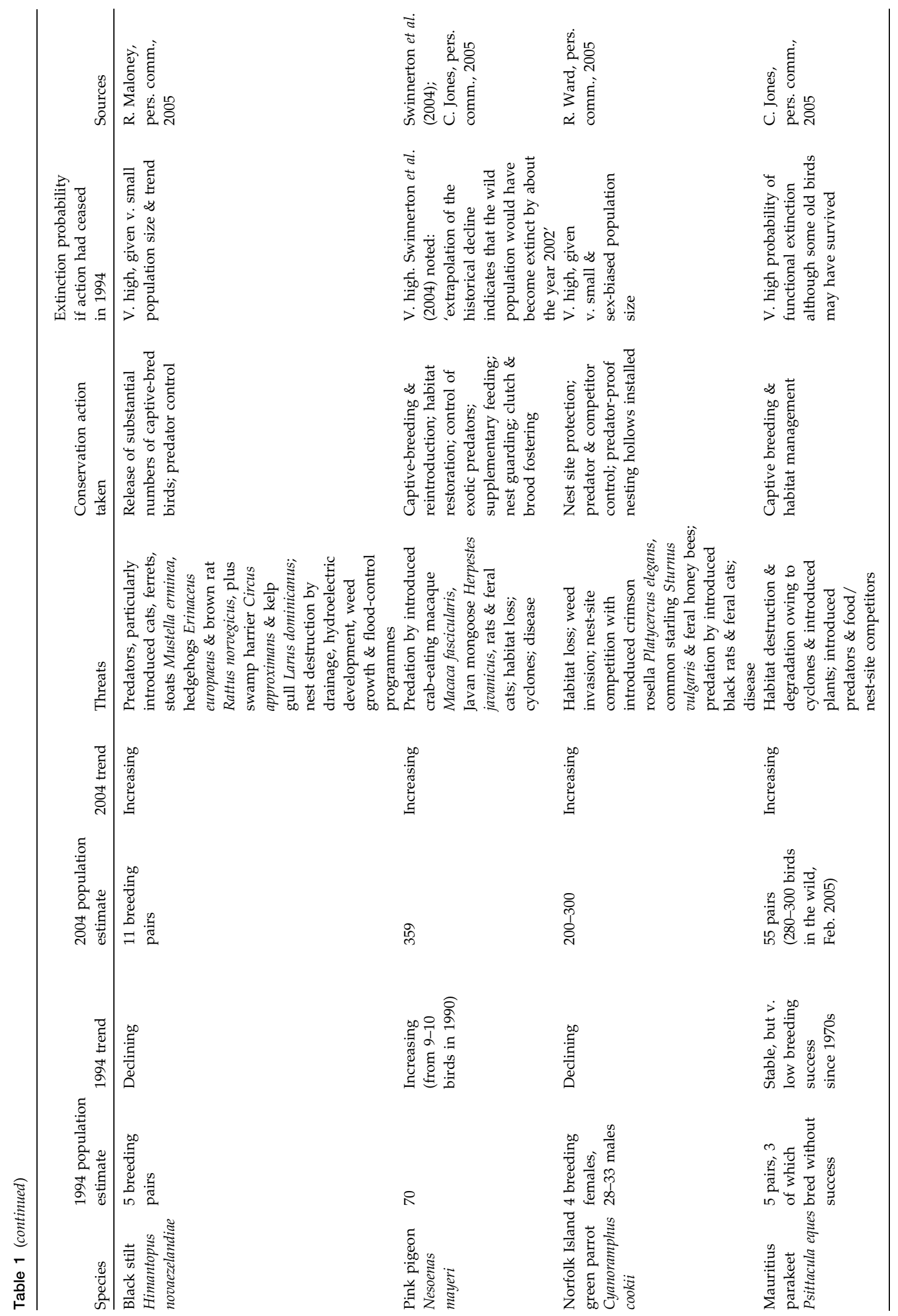

(c) 2006 FFI, Oryx, 40(3), 266-278 


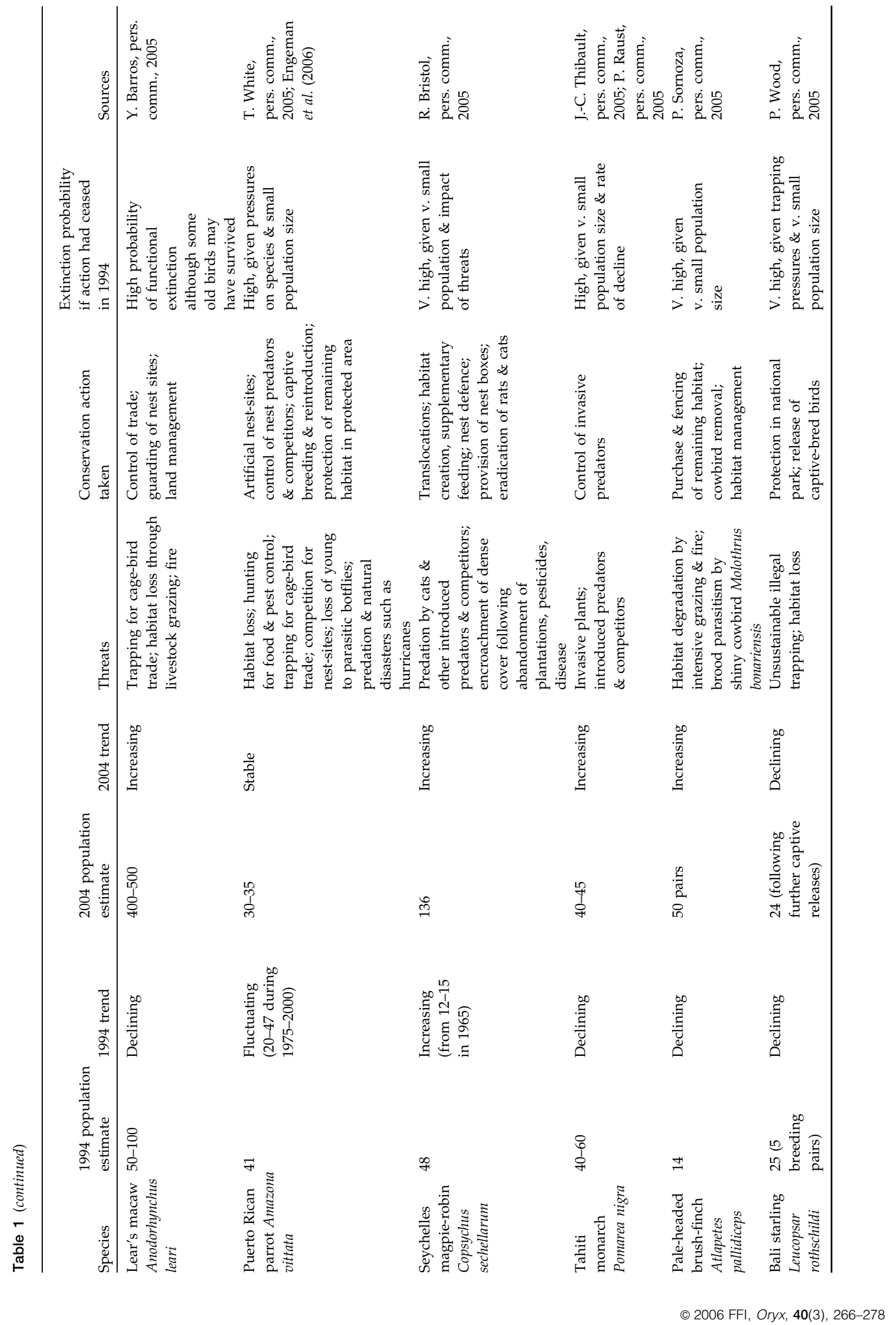




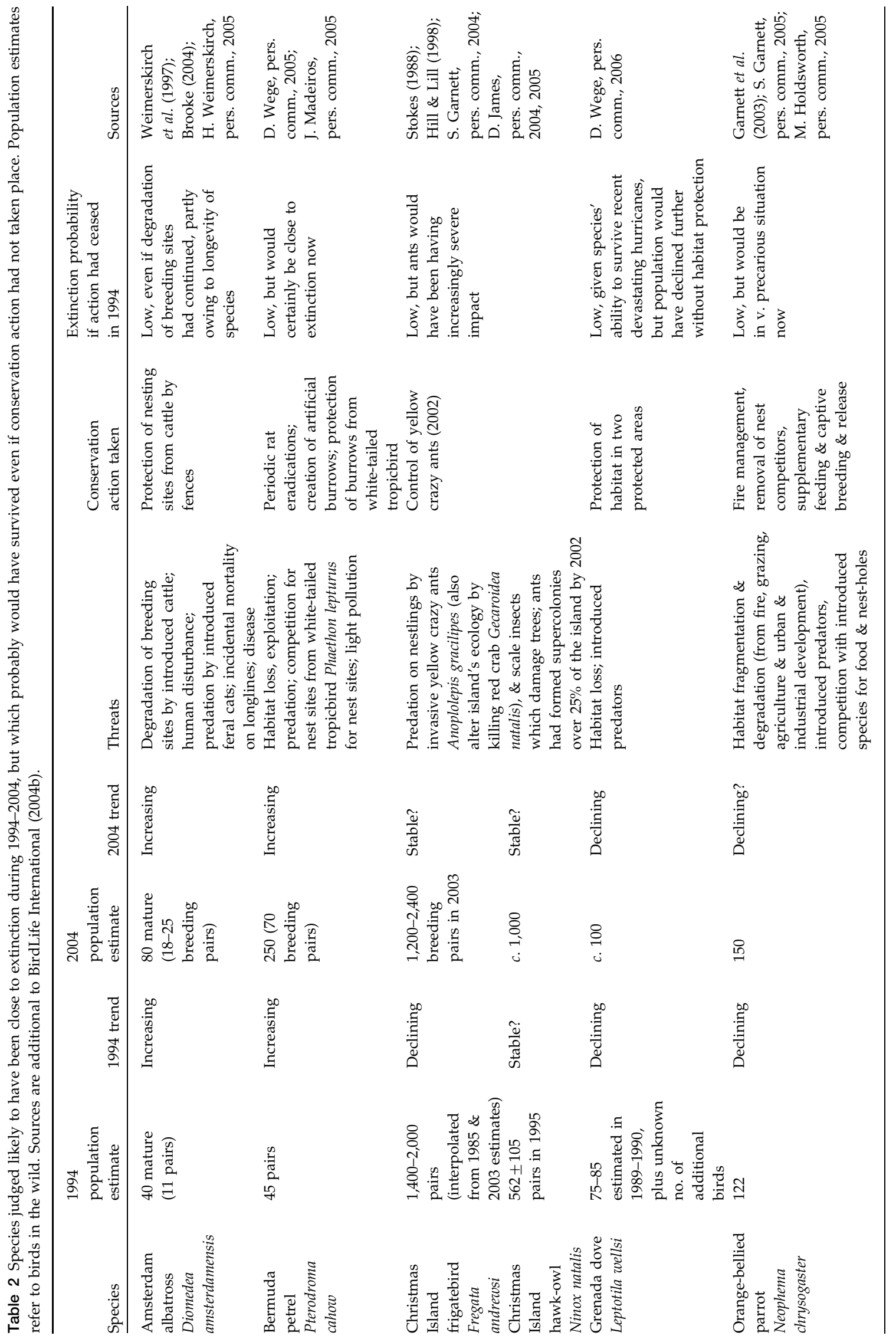




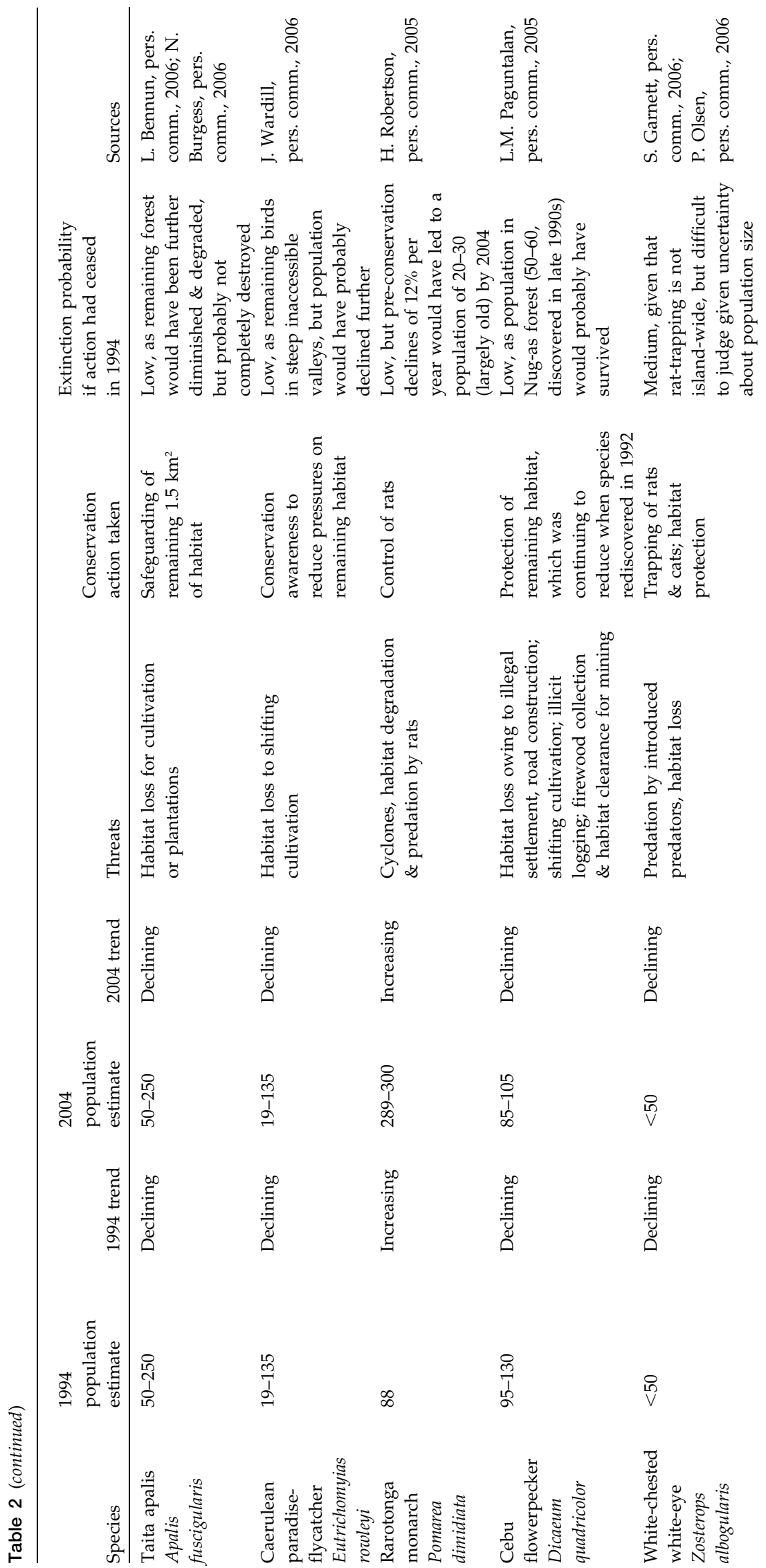


Table 3 Population trends of species prevented from going extinct during 1994-2004 (figures give number of species for each type of trend; $\mathrm{n}=16$ ).

\begin{tabular}{lll}
\hline Trend & 1994 & 2004 \\
\hline Increasing & $3(18.8 \%)$ & $13(81.3 \%)$ \\
Stable & $2(12.5 \%)$ & $1(6.3 \%)$ \\
Fluctuating & $1(6.3 \%)$ & 0 \\
Declining & $10(62.5 \%)$ & $2(12.5 \%)$ \\
\hline
\end{tabular}

condor being taken into captivity again in 1994. By 2004, these species' mean minimum population size had increased significantly to 147 individuals (range 22-400 breeding individuals, where these data are available; paired $t$-test: $\left.t_{18}=-3.82, \mathrm{P}=0.0017\right)$. Some species underwent very significant population increases. For example, the population of crested ibis Nipponia nippon increased 16-fold from 22 to 360 individuals (although there is some question over the accuracy of the earlier figures), Norfolk Island green parrot increased almost 10-fold from 32-37 individuals to 200-300 individuals, and Mauritius parakeet Psittacula eques increased 10-fold from five to 55 pairs.

Populations of $63 \%$ of these species were declining in 1994, with two being stable, one fluctuating, and three increasing in numbers owing to conservation measures already in place (crested ibis, pink pigeon Nesoenas mayeri and Seychelles magpie-robin Copsychus sechellarum; Table 3). By 2004 these figures had improved: only two were still declining (Junín grebe Podiceps taczanowskii and Bali starling Leucopsar rothschildi), one was stable and the remainder were increasing.

The majority of these species (63\%, 10 species) are found on islands (Fig. 1), including breeding colonies of two seabirds (Chatham Island taiko and Zino's petrel Pterodroma madeira). This is a higher proportion than for other species that would have qualified as Critically Endangered in 1994 (58\%, 93/160 species) or for other threatened species (45\%,518/1,199 species), although in neither case are the differences significant (extinction prevented vs other Critically Endangered species: $\chi^{2}=$ $0.11, \mathrm{P}=0.73$; extinction prevented vs other threatened species: $\chi^{2}=1.79, \mathrm{P}=0.18$ ).

Multiple factors led to the declines in all of the 16 species whose extinction was prevented, but the principal threats were habitat loss and degradation (88\% of species), invasive species (50\%) and exploitation $(38 \%)$. This is similar to the pattern for the 1,199 other species of threatened birds, but with exploitation and invasive species being relatively more important (Fig. 2). Pollution and persecution were more important threats

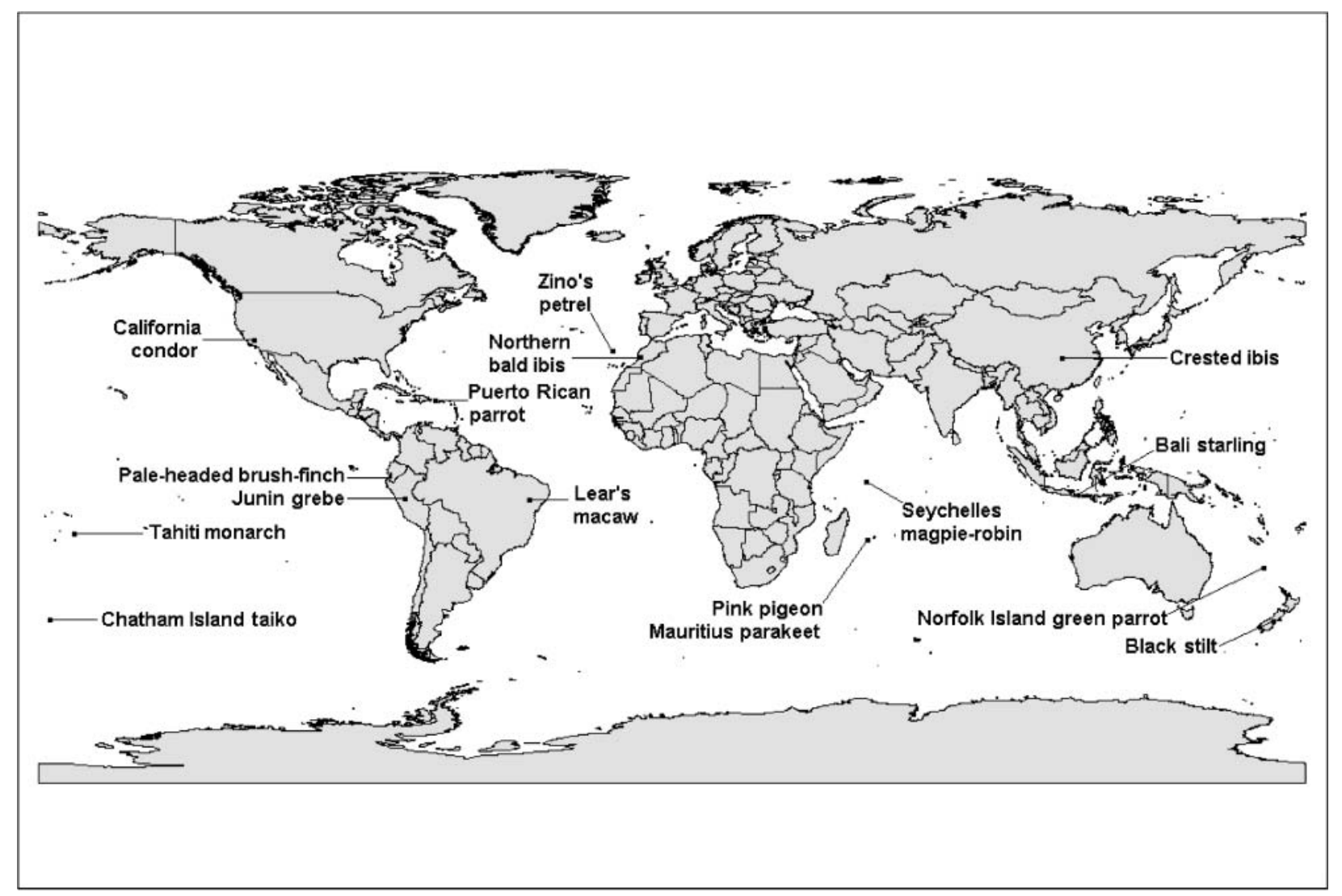

Fig. 1 Location of species whose extinction was prevented during 1994-2004. 


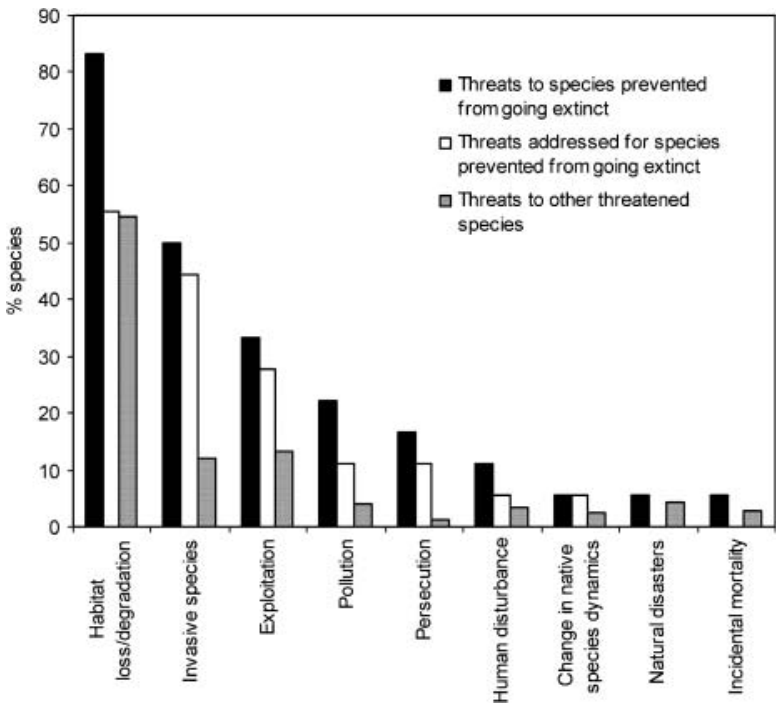

Fig. 2 Threats to species whose extinction was prevented during 1994-2004 $(\mathrm{n}=16)$, the threats addressed by conservation actions for these species, and threats to other threatened species $(n=1,199)$.

to the species whose extinction was prevented than to other threatened species, affecting 19 and $25 \%$ of the 16 species respectively, compared to 3.9 and $1.1 \%$ of other threatened species. That invasive species were the most important threat to half of the species that avoided extinction is not surprising, given that the extinctions prevented were concentrated on islands, where native birds are often susceptible to the effects of introduced herbivores, competitors and, most importantly, predators.

The types of conservation action carried out for these species included habitat protection and management (12 species; $75 \%$ ), control of invasive species $(8 ; 50 \%)$, captive breeding and release $(6 ; 33 \%)$, and translocation of individuals $(1 ; 6 \%)$. The main threats that these actions successfully addressed to allow the species to recover (or at least slowed their rate of decline) were habitat degradation $(50 \%)$, invasive species $(50 \%)$, exploitation $(31 \%)$ and, to a lesser extent, pollution $(13 \%)$ and persecution (13\%; Fig. 2).

Conservation actions were implemented through a mixture of both governmental and non-governmental agencies in the majority of cases (11 species, 69\%), with governments alone being responsible in the other cases (5, 31\%, in New Zealand, Australia, China and the USA). BirdLife International, the largest global alliance of national conservation organizations, contributed to the implementation of action for seven species (44\%). One such national organization (Taporoporoanga Ipukarea Society in the Cook Islands) grew out of efforts to save the Rarotonga monarch Pomarea dimidiata from extinction.
Although public appeal is difficult to quantify, the 16 species include $12(75 \%)$ that can be considered charismatic and popular, comprising four parrots, four waterbirds, one raptor, one pigeon and two attractive passerines. Among other species that qualified as Critically Endangered in 1994, only $48 \%$ were charismatic $\left(77 / 160\right.$ species, $\left.\chi^{2}=4.20, P=0.04\right)$, suggesting that public appeal is one parameter favouring successful conservation intervention. This may be because charismatic species capture conservationists' attention more easily, are easier to raise funds for, and/or are easier to change public opinion about (and hence the actions of hunters, farmers or landowners).

\section{Discussion}

We estimate that conservation efforts prevented at least 16 species from going extinct during 1994-2004. This estimate is based on consideration of the population size and trends of these species in 1994, the severity of threats, and the nature and intensity of conservation efforts carried out over the period. Ideally, sufficient data would have been available to run population viability analyses (Beissinger \& McCullough, 2002) for each species in order to quantify their probability of extinction with and without conservation interventions. For Amsterdam albatross Diomedea amsterdamensis (a species we judge would have probably survived even if conservation action had ceased in 1994) Weimerskirch et al. (1997) modelled the projected population size if long-line fishing recommenced, and predicted a likely extinction around 2045. However, they did not model the effects on the population size if measures on the breeding island ceased (e.g. exclusion of cattle from breeding areas), which would have certainly hastened their projected extinction trajectory. Unfortunately, data were unavailable to carry out similarly detailed population modelling for the remaining 16 species.

In addition to the species that we judge survived in the wild only through implementation of conservation programmes, four species survived only in captive breeding programmes during 1994-2004 (and are classified as Extinct in the Wild): Alagoas curassow Crax mitu (survived in the wild until 1988), Guam rail Gallirallus owstoni (1987), Socorro dove Zenaida graysoni and Hawaiian crow (2002). Since 2001 Spix's macaw also probably survives only in captivity (being classified as Possibly Extinct in the Wild), with the last known wild individual disappearing in 2001.

We examined this issue only at the species level. Conservation action is also likely to have prevented extinctions of some subspecific taxa during the period, e.g. the helmeted honeyeater subspecies of yellow-tufted honeyeater Lichenostomus melanops cassidix and the 
northern subspecies of eastern bristlebird Dasyornis brachypterus monoides (Garnett et al., 2003).

We also focused only on the decade 1994-2004, but at least 10 other species would very probably have gone extinct without conservation interventions prior to 1994, e.g. black robin Petroica traversi was reduced to five individuals in 1980, and Mauritius kestrel Falco punctatus fell to four individuals in the wild in 1974 (Table 4). This total is probably an underestimate as considerably less information is available prior to 1994.

These successes show that preventing extinctions is possible, given political will and concerted action. This is not a particularly surprising result, but it is instructive to examine the characteristics of each species. The majority $(88 \%$ of species that avoided extinction prior to 1994 and 63\% during 1994-2004 respectively) are restricted to islands, where invasive species are often one of the most important threats. Two thirds (67\%) of threatened birds on oceanic islands suffer negative impacts from invasive species (BirdLife International, 2004a). In recent decades technological advances and intense research, particularly in New Zealand, mean that eradicating invasive species is now a practical and feasible conservation option, even on sizeable islands (Myers et al., 2000; Veitch \& Clout, 2002). Furthermore, habitat management and restoration, and protection from exploitation, may be easier to implement on islands owing to the restricted scale at which action is required. This means that although island species tend to have greater inherent susceptibility to extinction from anthropogenic factors (owing to naiveté to mammalian predators, and naturally small populations), their conservation may be more practicable than for continental species that frequently require action to address broadscale habitat loss and degradation. More than half (54\%) of threatened birds are continental (BirdLife International, 2004a). Preventing extinctions among this suite of species will be an even greater challenge.

Most $(81 \%)$ of the species whose extinctions were prevented also qualify as trigger species under the Alliance for Zero Extinction initiative (AZE, 2005), a programme to identify all sites worldwide holding the last remaining populations of any Critically Endangered or Endangered species of animal or plant (Ricketts et al., 2005). This means that in each case $>95 \%$ of the global population of the species is believed to be confined to a single discrete site. The exceptions are more wideranging species (California condor and northern bald ibis Geronticus eremita), or species that have recovered so successfully that they have been downlisted to Vulnerable, and hence do not qualify under the Alliance's criteria (Mauritius parakeet).

While we believe that the 16 species would have gone extinct in the absence of conservation, they are by no means saved from the threat of extinction. Some can barely be seen as conservation successes: Bali starling maintains a population in the wild solely through the continued release of captive-bred birds, owing to the difficulty of preventing illegal trapping of the remaining birds, and the population of Junín grebe continues to decline owing to inappropriate water-level regulation at the sole lake where it is found. More intense action is needed to reverse the declines in these two species. Many of the other species still have very small populations and are reliant on continued conservation efforts to sustain or increase their current population.

Furthermore, the 16 species whose extinction was prevented by conservation action over the last decade represent only $8.9 \%$ of the 179 bird species classified in 2005 as Critically Endangered, and 1.3\% of the 1,212 bird species currently threatened with extinction (BirdLife International, 2006). Another 203 Critically Endangered or Endangered species are each also now restricted to single discrete sites and hence highly susceptible to extinction (Ricketts et al., 2005).

Many other bird species have slipped closer to extinction over this same time period: a total of 164 deteriorated in status sufficiently to be uplisted to higher categories of extinction risk on the IUCN Red List during 1994-2004 (Butchart et al., 2004, 2005). In addition, many species showed reduced populations or increasing rates of decline, but not at a rate sufficient to cross thresholds for higher categories on the IUCN Red List. For example, at least $45 \%$ of threatened bird species were judged to have deteriorated in status between 2000 and 2004 alone (BirdLife International, 2004a).

Therefore, despite the apparent substantial resources spent on conserving some species, we need to scale up our efforts considerably to prevent wholesale biodiversity loss and many more extinctions in the coming decades. This will require a combination of actions including: (1) research on distribution, population size and trends, ecology and threats; (2) monitoring; (3) identification of a network of key sites (Important Bird Areas; Fishpool \& Evans, 2001); (4) safeguarding and managing these sites under a range of governance mechanisms through legal protection in conjunction with local community initiatives; (5) intensive recovery programmes; (6) public awareness and education; (7) broad-scale habitat approaches; (9) policy interventions at multiple scales. For most species this will require coordinated efforts implemented through collaboration and partnerships between governments, non-governmental organizations, business and private individuals.

The examples we have highlighted show that we have the knowledge and tools to achieve this. To mobilize the resources and political will to apply them presents an enormous and urgent challenge to the 


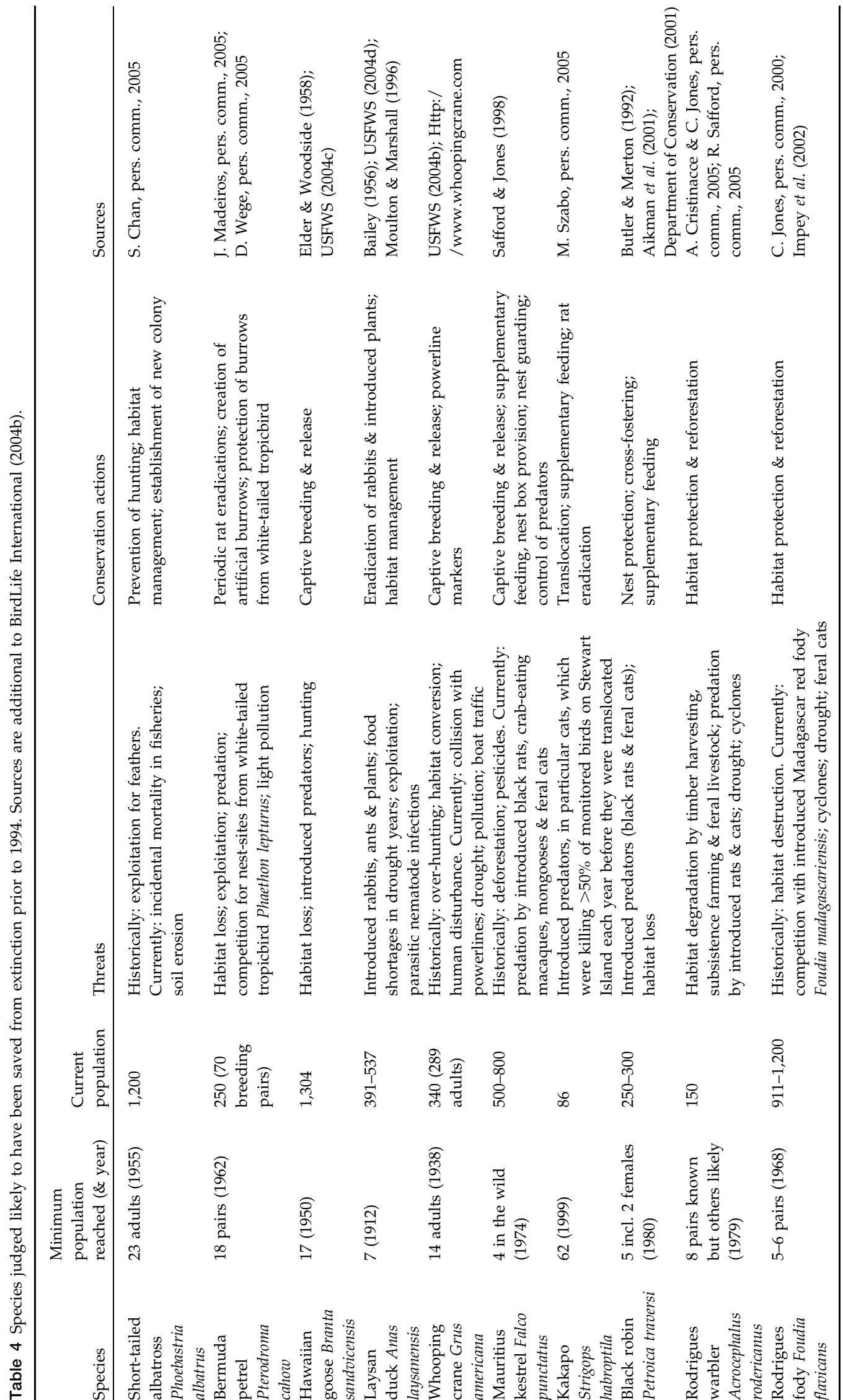


conservation community, but one we must rise to. Future generations will measure how well we meet this challenge by the number of extinctions we succeed or fail in preventing in the coming decades.

\section{Acknowledgements}

We thank the many species experts who provided us with population estimates and other information on the species discussed here: Y. Barros, L. Bennun, C. Bowden, R. Bristol, N. Burgess, S. Chan, Ding Changqing, A. Cristinacce, J. Fjeldså, S. Garnett, M. Holdsworth, C. Jones, D. James, J. Madeiros, R. Maloney, P. Olsen, L.M. Paguntalan, F. Iván Ramírez, P. Raust, H. Robertson, R. Safford, P. Sornoza, G. Taylor, J.-C. Thibault, R. Ward, J. Wardill, D. Wege, H. Weimerskirch, T. White and P. Wood, plus Stuart Pimm, John Lamoreux and an anonymous reviewer for helpful comments on earlier drafts.

\section{References}

Aikman, H., Davis, A., Miskelly, C., O'Connor, S. \& Taylor, G. (2001) Chatham Islands Threatened Birds: Recovery and Management Plans. Department of Conservation, Wellington, New Zealand.

Anon. (2005) Ivory-bill takes perch on money tree. Birder's World, December, 18.

AZE (Alliance for Zero Extinction) (2005) Http:// www.zeroextinction.org/ [accessed 15 June 2006]

Bailey, A.M. (1956) Birds of Midway and Laysan Islands. Denver Museum of Natural History, Museum Pictorial, 12.

Beissinger, S.R. \& McCullough, D.R. (eds) (2002) Population Viability Analysis. University of Chicago Press, Chicago, USA.

BirdLife International (2000) Threatened Birds of the World. Lynx Edicions and BirdLife International, Barcelona, Spain and Cambridge, UK.

BirdLife International (2001) Threatened Birds of Asia: The BirdLife International Red Data Book. BirdLife International, Cambridge, UK.

BirdLife International (2004a) State of the World's Birds 2004. BirdLife International, Cambridge, UK.

BirdLife International (2004b) Threatened Birds of the World 2004 (CD-ROM). BirdLife International, Cambridge, UK.

BirdLife International (2006) Data Zone. Http:// www.birdlife.org/datazone [accessed 15 June 2006].

Brooke, M. de L. (2004) Albatrosses and Petrels across the World. Oxford University Press, Oxford, UK.

Butchart, S.H.M., Stattersfield, A.J., Bennun, L.A., Akçakaya, H.R., Baillie, J.E.M., Stuart, S.N., Hilton-Taylor, C. \& Mace, G.M. (2005) Using Red List Indices to measure progress towards the 2010 target and beyond. Philosophical Transactions of the Royal Society B, 1454, 255-268.

Butchart, S.H.M., Stattersfield, A.J., Bennun, L.A., Shutes, S.M., Akçakaya, H.R., Baillie, J.E.M., Stuart, S.N., Hilton-Taylor, C. \& Mace, G.M. (2004) Measuring global trends in the status of biodiversity: Red List Indices for birds. Public Library of Science, Biology, 2, 2294-2304.

Butchart, S.H.M., Stattersfield, A.J. \& Brooks, T.M. (2006) Going or gone: defining 'Possibly Extinct' species to give a truer picture of recent extinctions. Bulletin of the British Ornithologists' Club, 126A, 7-24.

Butler, D. \& Merton, D. (1992) The Black Robin: Saving the World's Most Endangered Bird. Oxford University Press, Auckland, New Zealand.

Collar, N.J., Corsby, M.J. \& Stattersfield, A.J. (1994) Birds to Watch 2: The World List of Threatened Birds. BirdLife International, Cambridge, UK.

Department of Conservation (2001) Black Robin Recovery Plan 2001-2011. Department of Conservation, Wellington, New Zealand.

Diamond, J.M. (1987) Extant unless proven extinct? Or, extinct unless proven extant? Conservation Biology, 1, 77-79.

Elder, W.H. \& Woodside, D.H. (1958) Biology and management of the Hawaiian Goose. Transactions of the North American Wildlife Conference, 23, 198-215.

Engeman, R., Whisson, D., Quinn, J., Cano, F., Quiñones, P. \& White Jr, T.H. (2006) Monitoring invasive mammalian predator populations sharing habitat with the Critically Endangered Puerto Rican parrot Amazona vittata. Oryx, 40, 95-102.

Fishpool, L.D.C. \& Evans, M.I. (2001) Important Bird Areas in Africa and Associated Islands. BirdLife International and Nature Bureau, Cambridge and Newbury, UK.

Fjeldså, J. (2005) Grebes. Oxford University Press, Oxford, UK.

Garnett, S., Crowley, G. \& Balmford, A. (2003) The costs and effectiveness of funding the conservation of Australian threatened birds. BioScience, 53, 658-665.

Hilhorst, M. (2000) Reborn petrel on the up. BBC Wildlife, 18, 59.

Hill, F.A.R. \& Lill, A. (1998) Density and total population estimates for the threatened Christmas Island hawk-owl Ninox natalis. Emu, 98, 209-220.

Impey, A.J., Côté, I.M. \& Jones, C.G. (2002) Population recovery of the threatened endemic Rodrigues fody Foudia flavicans (Aves, Ploceidae) following reforestation. Biological Conservation, 107, 299-305.

IUCN (2001) 2001 Categories and Criteria (version 3.1). IUCN, Gland, Switzerland [http://www.redlist.org/info/ categories_criteria2001.html, accessed 14 June 2006].

IUCN (2006) IUCN Red List of Threatened Species: Threats Authority File. Http://www.redlist.org/info/ major_threats.html, accessed 14 June 2006.

James, A., Gaston, K.J. \& Balmford, A. (2001) Can we afford to conserve biodiversity? BioScience, 51, 43-52.

Jenkins, M., Green, R.E. \& Madden, J. (2003) The challenge of measuring global change in wild nature: are things getting better or worse? Conservation Biology, 17, 20-23.

Meretsky, V.J., Snyder, N.F.R., Beissinger, S.R., Clendenen, D.A. \& Wiley, J.W. (2000) Demography of the Californian Condor: implications for reestablishment. Conservation Biology, 14, 957-967.

Moulton, D.W. \& Marshall, A.P. (1996) Laysan Duck (Anas laysanensis). In The Birds of North America, No. 242 (eds A. Poole \& F. Gill). The Academy of Natural Sciences and The American Ornithologists' Union, Philadelphia and Washington, D.C., USA.

Myers, J.H., Simberloff, D., Kuris, A.M. \& Carey, J.R. (2000) Eradication revisited: dealing with exotic species. Trends in Ecology and Evolution, 15, 316-320.

Pimm, S.L. \& Brooks, T.M. (1999) The sixth extinction: how large, how soon, and where? In Nature and Human Society: The Quest for a Sustainable World (ed. P.H. Raven), pp. 46-62. National Academy Press, Washington, D.C., USA.

Ricketts, T.H., Dinerstein, E., Boucher, T., Brooks, T.M., Butchart, S.H.M., Hoffmann, M., Lamoreux, J.F., Morrison, J., 
Parr, M., Pilgrim, J.D., Rodrigues, A.S.L., Sechrest, W., Wallace, G.E., Berlin, K., Bielby, J., Burgess, N.D., Church, D.R., Cox, N., Knox, D., Loucks, C., Luck, G.W., Master, L.L., Moore, R., Naidoo, R., Ridgely, R., Schatz, G.E., Shire, G., Strand, H., Wettengel, W. \& Wikramanayake, W. (2005) Pinpointing and preventing imminent extinctions. Proceedings of the National Academy of Sciences, USA, 51, 18497-18501.

Safford, R.J. \& Jones, C.J. (1998) Strategies for land-bird conservation on Mauritius. Conservation Biology, 12, 169-176.

Secretariat of the Convention of Biological Diversity (2003) Handbook of the Convention on Biological Diversity. 2nd edition. Earthscan, London, UK.

Snyder, N.F.R. \& Schmitt, N.J. (2002) California Condor (Gymnogyps californianus). In The Birds of North America, No. 610 (eds A. Poole \& F. Gill). The Academy of Natural Sciences and The American Ornithologists' Union, Philadelphia and Washington, D.C., USA.

Stokes, T. (1988) A review of the birds of Christmas Island, Indian Ocean. Australian National Parks Wildlife Service, Occasional Paper no. 16.

Swinnerton, K.J., Groombridge, J.J., Jones, C.G., Burn, R.W. \& Mungroo, Y. (2004) Inbreeding depression and founder diversity among captive and free-living populations of the endangered Pink Pigeon Columba mayeri. Animal Conservation, 7, 353-364.

USFWS (US Fish and Wildlife Service) (2004a) President seeks $\$ 1.3$ billion for USFWS. Http://news.fws.gov/newsreleases/ r9/97DB824B-C168-4E11-8AABCFE5CDF8A58E.html [accessed 19 June 2006].

USFWS (US Fish and Wildlife Service) (2004b) Whooping crane population reaches record high. Http://news.fws.gov/ NewsReleases/R2/8F4A82F1-EE32-D71A21F0F54EC683910C.html, accessed 14 June 2006.

USFWS (US Fish and Wildlife Service) (2004c) Draft Revised Recovery Plan for Néné or Hawaiian Goose (Branta sandvicensis). US Fish and Wildlife Service, Portland, Oregon, USA.
USFWS (US Fish and Wildlife Service) (2004d) Draft Revised Recovery Plan for the Laysan Duck (Anas laysanensis). US Fish and Wildlife Service, Portland, Oregon, USA.

Veitch, C.R. \& Clout, M.N. (eds) (2002) Turning the Tide: The Eradication of Invasive Species. IUCN SSC Invasive Species Specialist Group, Gland, Switzerland and Cambridge, UK. Weimerskirch, H., Brothers, N. \& Jouventin, P. (1997) Population dynamics of wandering albatross Diomedea exulans and Amsterdam albatross D. amsterdamensis in the Indian Ocean and their relationships with long-line fisheries: conservation implications. Biological Conservation, 79, 257-270.

\section{Biographical sketches}

Stuart Butchart coordinates BirdLife International's Global Species Programme, which has the aim of conserving the world's birds through determining the species at highest risk of extinction and the factors that threaten them, and by identifying and supporting implementation of the conservation measures needed to save them. His research interests include extinction risk assessment, correlates of threat, extinction rates, biodiversity indicators and the impact of conservation action.

Alison Stattersfield's research interests span the field of bird conservation, from identifying site-scale targets for conserving the world's birds to assessing irreplaceability and threat at the species level. Her work includes development and application of the Endemic Bird Area concept, and development of a coherent suite of indicators to monitor trends in the state of biodiversity.

Nigel J. Collar is Leventis Fellow in Conservation Biology at BirdLife International, where he has been senior author/ editor of the international Red Data Book series. 